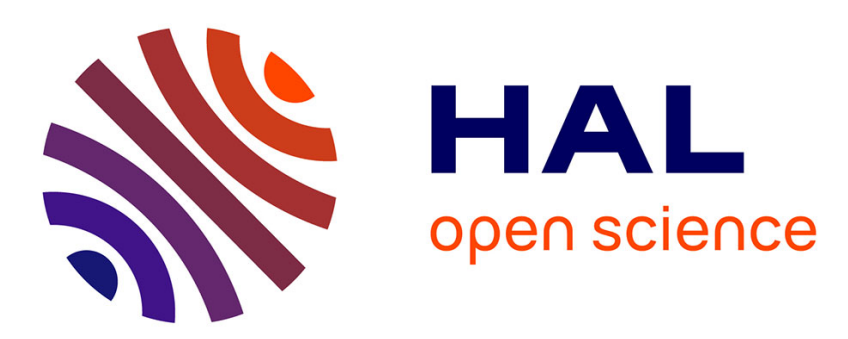

\title{
OPHTHALMIC DEVICES FOR CORNEAL MICROSURGERY ON EXCIMER LASERS
}

\author{
A. Razhev, V. Lantukh, M. Pyatin
}

\section{To cite this version:}

A. Razhev, V. Lantukh, M. Pyatin. OPHTHALMIC DEVICES FOR CORNEAL MICROSURGERY ON EXCIMER LASERS. Journal de Physique IV Proceedings, 1991, 01 (C7), pp.C7-235-C7-237. 10.1051/jp4:1991760 . jpa-00251002

\section{HAL Id: jpa-00251002 https://hal.science/jpa-00251002}

Submitted on 1 Jan 1991

HAL is a multi-disciplinary open access archive for the deposit and dissemination of scientific research documents, whether they are published or not. The documents may come from teaching and research institutions in France or abroad, or from public or private research centers.
L'archive ouverte pluridisciplinaire HAL, est destinée au dépôt et à la diffusion de documents scientifiques de niveau recherche, publiés ou non, émanant des établissements d'enseignement et de recherche français ou étrangers, des laboratoires publics ou privés. 


\title{
OPHTHALMIC DEVICES FOR CORNEAL MICROSURGERY ON EXCIMER LASERS
}

\author{
A.M. RAZHEV, V.V. LANTUKH and M.M. PYATIN \\ Institute of Laser Physics, Siberian Branch of the USSR Academy of Sciences, 13/3 Lavrentyev Pr., \\ Novosibirsk 630090, USSR \\ "Eye Microsurgery" R. \& T. Complex, Novosibirsk Affiliated Branch, 10 Kolkhidskaya St., \\ Novosibirsk 630071, USSR
}

\begin{abstract}
The results of studying the interaction of the excimer laser UV radiation and the eye cornea are discussed. A KrCl excimer Iaser (223 nm) is proposed for corneal microsurgery. Ophthalmic devices have been designed to correct myopia and hyperopia and to treat Herpes Simplex keratitis, corneal ulcers and glaucoma.
\end{abstract}

\section{Introduction.}

The first pulsed excimer ArF, $\mathrm{KrCl}, \mathrm{XeCl}$ lasers (193 nm, $223 \mathrm{~nm}, 308 \mathrm{~nm}$ ) were described in $[1,2]$. In 1983 Trokel [3] showed that the excimer laser $(193 \mathrm{~nm})$ can be used for refractive surgery on the cornea of the eye. The radiation of the ArF excimer laser possessing a great photon energy $(6.4 \mathrm{eV})$ was supposed to be able to perform refractive surgery by removing corneal lamellae of a controlled thickness with a negligible thermal effect on the adjacent cornea. As shown in later papers [3-7] for similar purposes an attempt was made to use the KrF excimer laser with the $248 \mathrm{~nm}$ wavelength. Nevertheless, the radiation of this laser is absorbed by the cornea in a weaker way than that of the $193 \mathrm{~nm}$ laser. Absorption coefficients are $210 \mathrm{~cm}^{-1}$ respectively [4]. As was found [7], this feature results in partial penetration of the $248 \mathrm{~nm}$ radiation through the entire corneal thickness and brings about damage of the Descemet's membrane and endothelium [6]. In addition to that thermal damage of the stroma is significantly more pronounced following the laser exposure.

In this paper we present the findings of the comparative analysis of the interaction of radiation at various wavelengths with the corneal tissues. On the basis of these findings an ophthalmic device for the treatment of eye disorders and corneal refractive surgery is designed.

\section{Experimental device.}

We have already described the design of the excimerlaser and radiation parameters at various wavelengths 8 . Here, we can only remark, that in order to increase reliability, effectiveness and resource of the excimer laser, its electric circuit design has been significantly simplified and will be described in one of our future papers. This is a design with an automatic UV pre-ionization in a horizontal plane. One 
high-volatge commutator self-triggered by the pulsed power source of the laseris used in it.

\section{Results.}

In our papers $[7,8]$ we showed the transmission of the human cornea in the range of 190-370 nm. The transmission curve demonstrated that the radiation in the range shorter than $290 \mathrm{~nm}$ practically does not penetrate the thickness of the cornea, but a weak degree of transmission $(1-2 \%)$ is observed up to $230 \mathrm{~nm}$, and for the $248 \mathrm{~nm}$ wavelength it is about $1,5 \%$. The absorption coefficient for this was measured and was equal to $210 \mathrm{~cm}^{-1}[4]$. Analysing the cornea transmission curve and the whole spectrum of laser wavelengths one can draw the conclusion that only 3 wavelengths can potentially be used in corneal surgery: $193 \mathrm{~nm}$ (ArF laser), $223 \mathrm{~nm}$ (KrCl laser) and $248 \mathrm{~nm}$ (KrF laser). We measured the cornea ablation rate at the three above mentioned wavelengths in the range of energy densities of $0.02-2.0 \mathrm{~J} / \mathrm{cm}^{2}[7,8]$. This relation is of non-linear character and if the energy density is higher than that determined for the given wavelength, the thickness of the ablated area does not change significantly and is $0.8 \mu \mathrm{m} ; 1.7 \mu \mathrm{m}$ and $2.6 \mu \mathrm{m}$ for the 193,223 and $248 \mathrm{~nm}$ wavelengths respectively.

The study of the zone of thermal damage deep inside the stroma was carried out after the corneal excision made by radiation in the form of a slit with the length of $4 \mathrm{~mm}$ and the width of $100 \mathrm{~mm}$ [7I. The results obtained showed that the eosinophilic damage zone is approximately si$\mathrm{mil}$ ar for the $193 \mathrm{~nm}$ and $223 \mathrm{~nm}$ wavelength $(1-2 \mu \mathrm{m})$, whereas for the $248 \mathrm{~nm}$ wavelength it is $10-15 \mu \mathrm{m}$.

Hence, to perform keratectomy an ophthalmic device based on KrCl excimer laser (223 $\mathrm{nm})$ is preferrable [9]. One can point out the following advantages of this laser over the $193 \mathrm{~nm}$ laser. The ablation rate is about two times that of the $193 \mathrm{~nm}$ laser and, consequently, to form a positive and negative menisci in the refractive corneal surgery fewer pulses of laser radiation are necessary. Thus the precision of surgery is enhanced. Damage of tissues adjacent to the area of ablation is about the same as that with the $193 \mathrm{~nm}$ laser. The $\mathrm{KrCl}$ laser has no toxic fluoride gas in the gas mixture. The life time of the KrCl gas mixture is longer than that of the Arf one. Besides, a longer wavelength is better transmitted through the optical system, allowing increased efficiency and prolonged life of the optics. No mutagenic effects have been found with this wavelength [7].

Devices consisting of excimer lasers and optics (delivery system) adapted to the operation microscopes were set up.

A set of change masks in the optics made it possible to emit energy of a pre-set energy density and to project a linear-slit on the cornea to correct astigmatism, to project a spot of a $0.2,0.5,0.1$ and $2.00 \mathrm{~mm}$ diameter to treat Herpes keratitis, corneal ulcers and open-angle glaucoma. To correct myopia and hyperopia a specially-designed figured aperture containing several "petals" was used to form a spot of a $3-5$ $\mathrm{mm}$ diameter $[10]$.

To treat Herpes Keratitis and corneal ulcers, radiation emitted at $223 \mathrm{~nm}$ and $248 \mathrm{~nm}$ with the energy density of 200 and $300 \mathrm{~mJ} / \mathrm{cm}^{2}$ was used, as the number of pulses was small and in all the cases only the epithelium or the upper part of the stroma had to be etched. The clinical outcome was better than with the $193 \mathrm{~nm}$ radiation.

All the three above-mentioned wavelengths were used to treat open-angle glaucoma. No clinical difference was found between the different lasers. But the $248 \mathrm{~nm}$ radiation is preferrable, as due to a greater energy density dissociation of the trabecular meshwork was 
more effective and non-transparent tissues were exposed to laser radiation. The $193 \mathrm{~nm}$ and $223 \mathrm{~nm}$ radiation was used to correct myopia and hyperopia. In several cases correction of myopia was performed by the $248 \mathrm{~nm}$ radiation for comparative analysis. A subtle haze of the cornea was characteristic for this wavelength. No haze was observed following the exposure to the $193 \mathrm{~nm}$ and $223 \mathrm{~nm}$ radiation. Thus, in this paper a laser device emitting energy at the $223 \mathrm{~nm}$ wavelength is proposed as an ophthalmic instrument alongside with other well known ophthaimic devices $(193 \mathrm{~nm})$. A more detailed description of the operation techniques mentioned above can be found in another paper by the same authors in this book.

1.Ищенко В.Н., Лисицын В.Н., Рахев А.М. Мощная сверхсветимость әксимеров ArF, KrF, XeF // Письма в ЖТФ. - I976. - Е.2. - Вып. I8. - C. 839-842.

2. Ishchenko V.N., Lisitsyn V.N., Razhev A.M. Efficient Discharge Pumping XeCI Laser // Optics Communications. - 1977. - Vol. 21. - N 1. p. 30-32.

3. Trokel S.L., Srinivasan R., Braren B. Excimer Laser surgery of the Cornea // Amer. J. of Ophthalmology. - 1983. - Vol. 96. - N 6. P. 710-715.

4.Puliafito C.A., Steinert R.F., Deutsch Th.F., Hillenkamp F., Dehm E.J., Adler C.M. Excimer Laser Ablation of the cornea and Lens // Ophthalmology. - 1985. - Vol. 92. - N 6. - P. 741-748.

5. Krueger R.R., Trokel B.L., Schubert H.D. Interaction of Ultraviolet Laser Light with the Cornea // Investigative Ophthalmology and Visual Science. - 1985. - Vol. 26. - N 11. - P. 1455-1464.

6. Dehm E.J., Pullafito C.A., Adler C.M., Steinert R.F. Corneal Endothelial Injury in Rabbits Following Excimer Laser Ablation at 193 and $248 \mathrm{~nm} / /$ Archives of Ophthalmology. - 1986. - Vol. 104. - P. $1364-1368$.

7. Лантух В.В., Плтин М.М., Искаков И.А., Ищенко В.Н., Кочубей С.А., Ражев А.М., Чеботаев В.П. Применение Ў әксимерных лазеров в микрохирургии глаза. - Новосибирск, I986. - I7 с. - (Препр./ АН СССР.Сиб. отделение, Ин-т теплофизики; I5I-86;.

8. Lantukh V.V., Pyatin M.M., Iskakov I.A., I shchenko V.N., Kochubei S.A., Razhev A.M., Chebotayev V.P. UV Excimer Laser in Eye Microsurgery // Lasers in the Life Sciences. 1988. - Vol. 2. - N 4. - P. 313-326.

9. Razhev A.M. Cornea microsurgery by UV radiation from an excimer laser // Summaries of papers, Conference CLEO-88. - Anaheim, California, 1988. - P. 334 .

10.Pat. P. 8902371 Spain. Device for Correcting Ocular Refraction Anomalies / S.N.Fyodorov, V.V.Lantukh, V.V.Pyatin, V.N.Ishchenko, S.A. Kochubei. A.M.Razhev, O.V.Rydannykh, A.V.Tsibizov, V.P.Chebotayev 